Article

\title{
'Forced' Online Religion: Religious Minority and Majority Communities' Media Usage during the COVID-19 Lockdown
}

\author{
Lene Kühle ${ }^{1}$ and Tina Langholm Larsen ${ }^{2, *(D)}$ \\ 1 Department of the Study of Religion, School of Culture and Society, Aarhus University, \\ 8000 Aarhus C, Denmark; 1k@cas.au.dk \\ 2 Department of the Study of Religions, Faculty of Humanities, University of Southern Denmark, \\ 5230 Odense, Denmark \\ * Correspondence: tll@sdu.dk
}

Citation: Kühle, Lene, and Tina Langholm Larsen. 2021. 'Forced' Online Religion: Religious Minority and Majority Communities' Media Usage during the COVID-19 Lockdown. Religions 12: 496. https://doi.org/10.3390/rel12070496

Academic Editors: Solange Lefebvre and Roberta Ricucci

Received: 31 May 2021

Accepted: 1 July 2021

Published: 3 July 2021

Publisher's Note: MDPI stays neutral with regard to jurisdictional claims in published maps and institutional affiliations.

Copyright: (C) 2021 by the authors. Licensee MDPI, Basel, Switzerland. This article is an open access article distributed under the terms and conditions of the Creative Commons Attribution (CC BY) license (https:/ / creativecommons.org/licenses/by/ $4.0 /)$.

\begin{abstract}
On 11 March 2020, the Danish Prime Minister announced a forthcoming lockdown of Danish society due to the COVID-19 pandemic and shut down all public institutions, including the national church. Instructions for the lockdown of religious minority communities were issued a week later. The total lockdown of the Danish religious landscape is both historically unprecedented and radical in a global context, and it raises questions about mediatized religion and religion-state relations in a postsecular society. Building on quantitative and qualitative data collected during the lockdown and the gradual opening of society in 2020, this article examines the media usage of the Danish national church and of the 28 recognized Muslim communities. It reevaluates Heidi A. Campbell's 'religious-social shaping approach to technology' by examining how religious communities sought to establish continuity between their offline and online practices to maintain authority and community cohesion. We conclude (1) that the willingness of religious communities to cooperate with authorities was high, (2) that the crisis affected religious communities' organizational framework and societal position, and (3) that Campbell's approach needs to pay further attention to the conflict-producing aspects of negotiations on digitalized rituals, the importance of transnationalism, and differences between minority and majority religion.
\end{abstract}

Keywords: online religion; COVID-19; postsecular religion; religious minority and majority communities; Denmark

\section{Introduction}

11 March 2020 constitutes a landmark date in Danish history, as this is the date when Danish Prime Minister Mette Frederiksen announced a forthcoming lockdown of Danish society due to the COVID-19 pandemic that would close all public institutions including the national church. Yet, from the perspective of the present article, the day after this historic announcement may be of greater importance, because on 12 March 2020, the Minister for Ecclesiastical Affairs, Joy Mogensen, quite exceptionally addressed religious minority communities in Denmark directly. In a one-minute video in Danish followed by an official written announcement in both Danish and English, Mogensen stated:

In light of the latest announcements from the Danish government and the health authorities, I strongly urge all religious communities in Denmark to organize religious acts in a way to avoid rapid spread [sic] of Corona infection. [ ... ] I strongly urge all religious communities in Denmark to similarly cancel all religious activities, church services, Friday prayers, Mass, etc. where many people are gathered in the same place for the next 14 days. Instead, the prayers could perhaps be videotaped and uploaded to your website. (Mogensen 2020)

This announcement is striking in three ways. Firstly, while the Danish lockdown in spring 2020 overall was less restrictive than lockdown in many other European countries, 
the religious lockdown has been regarded as one of the most extensive in Europe, because it included the closure of religious buildings not just for gatherings, but also for individual worship (La Ferrière 2020). When Mogensen's video was filmed and posted, the Danish government did not have the legal authority to close the buildings of religious minoritiesnot until April 5. Accordingly, the Minister for Ecclesiastical Affairs had to urge the minority communities to respond to her appeal by cancelling their activities and closing their buildings, which an impressive majority did without any complaints (Larsen et al. 2021a, 2021b). The reactions of Danish public authorities have been characterized as postsecular, implying that they have adopted a political mindset formed by an awareness that religious expressions will continue to exist in secular societies and that secular authorities need to deal with and regulate religion. Despite the existence of a strong relation between the majority Lutheran church, also known as folkekirken, Denmark has been and remains a very secular society with a secular state, but the concept of postsecular points to a new phase in this secularity in which the state does not only include the majority religion in the secular governance but also aims to include minority religions (Kühle 2021). ${ }^{1}$

Secondly, the minister suggested in the video that Danish religious organizations carry out their religious activities online. Many followed this suggestion and swiftly replaced all physical events with digital ones. This, of course, also points to the unusual circumstances under which religion has been practiced due to COVID-19. It is not uncommon for religious practices to take place online, but it is unusual that the move from an offline to an online religious sphere is done out of necessity by a large group of religious organizations and not voluntarily by those religious organizations that have the capacity, theological inclinations, and/or wish to reach a larger audience.

Thirdly, the video only addressed religious minorities, thereby exposing an asymmetrical relationship between the Danish state and the religious majority and minorities in Denmark. While the national church was rather quickly locked down from March 18 due to its status as a public state institution, religious minority communities were not part of the preliminary Epidemic Act promulgating the lockdown of religious buildings and activities. This is related to the close connection between the Danish state and folkekirken, which means that the pastors are civil servants and that the churches are effectively public buildings, which naturally included them in the lockdown of public institutions (Danish Epidemic Act of 18 March 2020). The production of both a Danish and an English version (in writing) of the message in the video by Mogensen seems to reveal a slip of the tongue. Where Mogensen in the Danish version speaks of the need to broadcast sermons (in Danish: "prædikener"), in the English version this becomes prayer. This may indicate that one particular group among the religious minorities in Denmark was of particular interest, the Muslim community, which is the largest religious minority in Denmark. In fact, Muslims received more negative attention during the pandemic than any other religious group in Denmark, despite the fact that the mosque associations appeared to be more eager than anyone else to present themselves as good citizens following the instructions from health authorities (Kühle 2021).

This total lockdown of the Danish religious landscape is thus not only historically unprecedented, it also encourages an exploration of how mediatized religion, religious change, and religion-state relations unfold in a postsecular society. Because of the social and collective character of religion, the lockdown is obviously a rare and potentially critical situation for religious communities, which are impelled to find new ways to express and develop the collective element of religion. While transformations of online religion have taken place for years, most research literature on digital religion, primarily focusing on the technologically progressive religious communities embracing the opportunities and advantages of online religion, has not explored the "forced" migration online similar to what religious communities worldwide experienced in spring 2020. Suddenly, digital media were no longer a supplement to offline religion, but the main platform for religious activities (cf. Campbell 2020b, p. 70). COVID-19 accelerated the digitization of religion for many religious groups and organizations, posing new research questions to the field 
of digital religion that relate to the extraordinary adaptivity, creativity, innovation, and entrepreneurship of religious groups. Parish (2020, p. 276) describes the new situation caused by COVID-19 rather precisely: "Such a seismic shift in social culture opens up the possibility and challenges of a new understanding of belonging and participation in a religious community". Scholarship on religion during the COVID-19 crisis has so far been quite descriptive, with the move from offline to online religion as a central element of discussions on pandemic religion (see e.g., Ahmad 2021; Al-Astewani 2021; Carlsen et al. 2020; Foley 2021; Larsen et al. 2021a, 2021b; Gori 2021; Hassan et al. 2021; Hörsch 2020; Kostecki and Piwko 2021; Kühle 2021; Morón et al. 2021; Parish 2020; Przywara et al. 2021; Riexinger 2021; Sabaté Gauxachs et al. 2021; Sulkowski and Ignatowski 2020; Tudor et al. 2021). The next step is to relate these empirical findings to the general research on religion and digitization in order to reevaluate the applicability and analytical value of the theoretical literature.

In this article, we reevaluate Heidi A. Campbell's seminal work on digital religion stemming from her book When Religion Meets New Media (2010). With her 'religious-social shaping approach to technology', Campbell presents a theoretical approach for studying "how individuals and groups within particular cultural contexts see their technological choices constrained by broader structural and social elements of their worldview and belief systems" (Campbell 2017, p. 20). It is obvious that Campbell's approach, which emphasizes how religious organizations choose to go online, does not sit well with a situation where religious organizations are strongly encouraged or may even feel forced to move their activities online. Yet, the specific conditions set by the COVID-19 pandemic reveal that topics like differences between religious minorities and majorities, the importance of transnational ties, and authority structures would also need to receive greater attention than what Campbell's approach offers. While changes to both minority and majority religion during the COVID-19 pandemic have been discussed side by side in many publications (see for instance Begovic 2020; Gori 2021; Kostecki and Piwko 2021), systematic attention has not been paid to how these processes of change may impact the digitization of religious minorities and majorities differently. In this article, we examine the consequences of "forced" media use, which for obvious reasons have not been a concern for Campbell or other digital religion scholars who have researched the topic under the 'normal' pre-COVID19 conditions. However, we suggest that the unusual conditions caused by the COVID-19 lockdown may contribute to nuance and expand Campbell's theoretical framework in three ways.

First, we suggest that Campbell may underestimate the importance of how the mediation of religion and particularly the digitization of rituals may produce conflict within a religious community. This argument is presented in this article based on a debate about virtual communion in folkekirken that has taken place in the Danish Christian newspaper Kristeligt Dagblad for more than a year, from spring 2020 to spring 2021. We investigate how the emerging conflicts within the majority church over media usage and the transition from offline to online religion have crystalized in the debate about virtual rituals. Second, we suggest that Campbell does not pay sufficient attention to the importance of transnational religion. This argument is made on the basis of studies of how Muslim organizations in Denmark reacted to the Minister for Ecclesiastical Affairs' suggestion to digitalize their activities. Finally, we suggest that a comparison of the asymmetrical impact of COVID-19 on religious minorities and majorities may provide an important new dimension to Campbell's approach. The distinction between religious minorities and majorities can be made in different ways. Like other concepts used both inside and outside academia, its usage is varied and contested (Kühle et al. 2018a). While it is possible to speak of the Evangelical-Lutheran Church as, in general terms, forming the majority religion in Denmark, which would mean that both folkekirken and free churches adhering to Confessio Augustana would belong to the religious majority, the approach taken in this article is to distinguish between minority and majority religion in relation to the legal categories, 
which means that folkekirken is considered as the majority religion, while other religious organizations are considered as religious minority organizations.

Overall, we suggest that Campbell's theoretical framework would benefit from paying closer attention to the legal, political, and economic differences between religious majorities and minorities. The COVID-19 pandemic exposes not only how history, tradition, and core beliefs define a religious community's response to technology, but also that discrimination, entitlement, state-religion relations, and resources (time, money, personnel, technological know-how) are decisive for the community's media use. Additionally, we suggest that further attention must be given to the topic of internal differences within the community, given that the religious community will not necessarily agree on one uniform media strategy and on transnational dimensions.

\section{Denmark: A Digital Nation with a State Church}

Denmark is a particularly interesting case in regard to the interplay between religious minorities and majorities, state regulation, and media. In Denmark, the relationship between the state and the majority church, which is Lutheran and counts 73.8 percent of the population as its members (Danmarks Statistik, January 2021), is exceptionally close. The national church, called the Evangelical-Lutheran Church in Denmark (in daily use known as folkekirken), has been identified as a mixture of a state church and a free church, with the former referring to the formal lack of autonomy of the church and the latter to the de facto high levels of local church autonomy (Nielsen and Kühle 2011). In relation to the three criteria of constitutional preference, legislative power (i.e., whether the state decides on church legislation), and executive power (whether the state exercises authority over the daily affairs of the church), the state and church are more integrated in Denmark than in the other Nordic countries (Kühle et al. 2018b). The Danish constitution clearly states that "The Evangelical Lutheran Church shall be the Established Church of Denmark and as such, it shall be supported by the State" ( $\$ 4$; https://www.constituteproject.org/constitution/Denmark_1953.pdf?lang=en accessed on 2 July 2021). The Evangelical-Lutheran Church furthermore lacks a synod, and all formal legislative power is thus entirely delegated to the parliament. In addition, the church has some formal hierarchy in the form of bishops but lacks a formal leader, and, in practice, the executive authority rests with the (political) Minister for Ecclesiastical Affairs. Accordingly, the Evangelical-Lutheran Church is simultaneously a public institution and a religious community with extensive internal democracy (FUV 2020). Islam is the largest minority religion in Denmark. Muslims are estimated to constitute approximately 5 percent of the Danish population. The number of mosques is estimated to be 185 , which, compared to the 2200 congregations within the national church, indicates that communal Muslim life is not below the number expected on the basis of the Muslim population. Other religious minorities in Denmark include Christian (Catholic and Orthodox) and Buddhist and Hindu communities. Legally, a number of minority religious associations have the position of socalled 'recognized religious communities', which is a position that religious organizations may apply for and if accepted, the religious organization receives a number of privileges from tax reductions to easier access to residence permits for religious personnel. It is thus individual religious organizations which are recognized, not the religions as such.

The identity of a public institution and a characteristic lack of autonomy combined with slow internal processes are some of the reasons why the initial Danish lockdown of religious activities and facilities was among the most extensive in Europe. Denmark, as part of the Scandinavian welfare model, "has a well-established but more liberal model of user choice, where local nonprofit alternatives flourish" (Sivesind and Trætteberg 2017, p. 8). The position of majority religion in Denmark is highly embedded in the welfare system, to which it contributes and constitutes a part (Markkola and Naumann 2014). The same applies to media, where Danish media may be characterized as part of a Northern/Central European or Democratic Corporatist Model with a specific Nordic twist of emphasis on the role of the media as a crucial watchdog in a democratic society (Olesen 2020). Furthermore, 
access to the internet is widespread in Denmark: In 2020, 95 percent of the population had internet access at home (Danmarks Statistik 2020). The social media penetration rate in Denmark is 69 percent and among the highest in Europe along with Sweden (72 percent), while Germany (45 percent) has one of the lowest (Statista 2021). In addition, social media has supplemented rather than replaced traditional media. The relationship between traditional Danish media and a platform like Facebook is in this way partly symbiotic as 92 percent of news stories are also shared on social media (Olesen 2020). During the COVID-19 lockdown, social media platforms like Facebook played an important part in sharing news and information about COVID-19, but also in organizing voluntary help, with over 300 civic support groups being organized within the first weeks of the lockdown period (Carlsen et al. 2020, p. 5).

\section{Materials and Methods}

This article builds on material from three research projects. The first study (Larsen et al. 2021a) is a study of how the 179 recognized religious communities in Denmark responded to and handled the lockdown of Danish society due to COVID-19 on their platforms such as Facebook, websites, Twitter, and Instagram. This study was conducted in the spring of 2020 (from March to May) and mainly focused on the initial reactions to the lockdown, but also looked into what kind of online activities followed. Although the religious communities responded online in extremely different ways and with different levels of activity, any kind of online response to the pandemic was coded as online activity. For each of the religious communities that were active online, the choices made regarding online platform and language were registered. This research design only attended to publicly accessible media platforms, meaning that closed online fora and communication were not detected. Similarly, the research design only included state-recognized religious communities, limiting the scope of this research project, and leaving out a number of Muslim and Hindu societies that have either not gained state recognition yet or do not wish to gain such recognition.

The second study (Larsen et al. 2021b) had religious change as its thematic focal point, including changes in organizational structures, the practical, social, and liturgical changes, and changes in user groups. The study was based on telephone interviews with 60 leaders and representatives from a wide range of Christian (21), Muslim (13), Buddhist (4), Hindu (3), and 'other' groups (19), all of which are located in the Aarhus area. ${ }^{2}$ Furthermore, we have also included the Humanist Society, which does not constitute a religious group but rather a philosophical group in the report. The telephone interviews were supplemented with a smaller number of semi-structured interviews with representatives of the religious groups. Each group representative was asked whether they had conducted any physical events during the lockdown. Religious buildings were closed to the public during lockdown, but while not encouraged, it was not illegal for the religious groups to gather in there if they were less than 10 persons. Groups were also asked if they had intensified their online communication, if they had offered any social or charitable services, and/or if they had continued any of these changes after the re-opening of Danish society. Given that this study comprises state-recognized religious groups as well as non-recognized groups, it includes Muslim and Hindu societies that have not been recognized by the Danish state. The following tables (Tables 1-4) illustrate the results of this study:

The third study (FUV 2020) was conducted in fall 2020 by researchers (Tina Langholm Larsen, among others) from the Centre for Pastoral Education and Research (FUV), an organization under the Ministry for Ecclesiastical Affairs. Focusing on how folkekirken responded to the lockdown of Danish society in spring 2020, this study reports on four major themes: the organizational alterations caused by the COVID-19 pandemic, the digital media utilized by the church to handle the crisis and uphold church activity, the theology of crisis disseminated offline and online during the lockdown, and the Danish population's attitudes towards the church during the COVID-19 pandemic. 
Table 1. Research question 1: Were there any activities in your buildings after the Minister of Church Affairs requested that religious buildings were closed to the public (e.g., sacrifices, recordings of sermons, and rituals for smaller congregations)?

\begin{tabular}{cccc}
\hline Religious Group & Yes & No & No Data \\
\hline Christian groups & 6 & 11 & 4 \\
\hline Muslim groups & 2 & 11 & - \\
\hline Hindu groups & 2 & 1 & 1 \\
\hline Buddhist groups & 2 & 1 & 1 \\
\hline Other groups & 8 & 10 & $6(10 \%)$ \\
\hline Total & $20(33 \%)$ & $34(57 \%)$ &
\end{tabular}

Table 2. Research question 2: Did you increase your online activities during the crisis?

\begin{tabular}{cccc}
\hline Religious Group & Yes & No & No Data \\
\hline Christian groups & 16 & 5 & - \\
\hline Muslim groups & 8 & 5 & - \\
\hline Hindu groups & 3 & - & - \\
\hline Buddhist groups & 3 & 1 & - \\
\hline Other groups & 12 & 7 & - \\
\hline Total & $42(70 \%)$ & $18(30 \%)$ &
\end{tabular}

Table 3. Research question 3: Have you offered non-religious, charitable services to lay members during the crisis (e.g., grocery shopping, dog walking)?

\begin{tabular}{cccc}
\hline Religious Group & Yes & No & No Data \\
\hline Christian groups & 10 & 7 & 4 \\
\hline Muslim groups & 8 & 5 & - \\
\hline Hindu groups & - & 2 & 1 \\
\hline Buddhist groups & 2 & - & 2 \\
\hline Other groups & 1 & 17 & $8(13 \%)$ \\
\hline Total & $21(35 \%)$ & $31(52 \%)$ &
\end{tabular}

Table 4. Research question 4: Have you continued any of the activities implemented during the first phase of the crisis (i.e., the closure of buildings from March to May)?

\begin{tabular}{cccc}
\hline Religious Group & Yes & No & No Data \\
\hline Christian groups & 11 & 4 & 6 \\
\hline Muslim groups & 3 & 9 & 1 \\
\hline Hindu groups & 2 & - & 1 \\
\hline Buddhist groups & 2 & - & 2 \\
\hline Other groups & 9 & 7 & 3 \\
\hline Total & $27(45 \%)$ & $20(33 \%)$ & $13(22 \%)$
\end{tabular}

\section{Review of Research Field(s)}

In this article, we focus on how religious communities seek to establish continuity between their offline and online practices in order to maintain authority and community cohesion during the COVID-19 lockdown of Danish society. This means that the transition 
from analogue, offline religion to virtual, online religion and the interplay between the offline and online fora will be key themes of this article. While COVID-19 certainly has been-and still is-causing significant changes in the religious sphere not only in Denmark but across the entire world, there is nothing new about either the mediation of religion or the digitization of religion.

Firstly, as Birgit Meyer argues, religion has always been mediated, and religion itself can be conceptualized as mediation (Meyer 2020). With this conceptualization of 'religion as mediation', Meyer defines media broadly, pointing to the fact that media such as bone inscriptions and books have mediated and shaped religion throughout the history of religions. However, other scholars of religion define media more narrowly as primarily digital mass media, thereby emphasizing the more recent macro-level transformations of traditional forms of religion caused by the logic of mass media. Instead of speaking of the mediation of religion, scholars of the latter research position engage with the mediatization of religion (Carneiro 2015). Attending to the social, political, and cultural structures and secularization of modern society, mediatization theory, as it is presented by Hjarvard (2008) and Lövheim (2011), offers an important lens to study the interrelations between media institutions and religion.

Secondly, the changes caused by the digitization of religion have for the last three decades laid the foundation for a distinct research field attending to the micro- and mesolevels of religion. Starting as a composite, interdisciplinary field of research in the 1990s, research on digital religion has gradually become an established research area gathering scholars from disciplines such as internet studies and media, religion, and culture studies (Campbell 2017). Key research questions have concerned the transformative processes propelled by new media technology, e.g., how the internet changes religious practices, ideology, and communities, how different religions respond to new media technologies, and how media technology forms new relations between online and offline religious lives (Campbell and Lövheim 2011). Particularly focused on the newly established online religious fora, research initially tended to approach online and offline religious communities as essentially different (see e.g., Helland 2000). However, Campbell and Lövheim (2011), among others, have since then argued that the online and offline religious activities of a religious community are not only interconnected but often also interdependent. Rather than seeing online and offline religion as separate phenomena, the two are inextricably linked and as the internet has become an integrated aspect of everyday life, the boundaries between online and offline religious spheres have become blurred. Online religious practices reflect larger trends in offline religious belief and practices, just as the users of online religion often derive from offline traditions, which means that their online practices may have implications for the offline group (Campbell and Lövheim 2011; Campbell 2017). Accordingly, Knut Lundby states that "offline and online lives and contexts are merging," continually eroding the distinction between online and offline forms of social interactions (Lundby 2011, p. 1224). Therefore, "[w]e can think of digital religion as a bridge that connects and extends online religious practices and spaces into offline religious contexts, and vice versa", Campbell contends (Campbell 2012, p. 4). Thus, research on digital religion recognizes not only that new media technologies have become embedded in our everyday lives, including the religious domain, but also that media technology offers particular affordances that may mold religion. Online religion, offline religion, and media technology are therefore seen as interrelated and mutually constitutive aspects of religion in modern societies.

Third, a novel approach, the 'religious-social shaping approach to technology' advocated by Campbell (2010, 2017; Campbell and Osteen 2020), offers "a frame that can provide valuable insights and a new depth of understanding into religious communities' choices related to media appropriation". (2010, p. 189) With this approach, Campbell argues that researchers must address four core areas that are decisive for how the religious community conceives of and applies new technologies. These four areas are history and tradition, core beliefs and patterns, negotiation processes, and communal framing and discourses 
(2010, pp. 59-60). Building on this foundation, she distinguishes between different forms of Judaism, Christianity, and Islam, arguing not only that religious communities' media usage is historically, socially, and religiously grounded, but also that the 'religious-social shaping approach to technology" "may help scholars predict future choices or responses to new technologies, based on previous trajectories" (2017, p. 21). Although the conditions for religious activities during the COVID-19 pandemic are unprecedented, forcing religious communities in Denmark to either shut down or migrate online, they offer an opportunity to test and evaluate Campbell's theoretical framework.

However, instead of applying her 'religious-social shaping approach to technology' to the COVID-19 situation, Campbell's newest research offers a new analytical strategy to religious communities' media use during the pandemic. Based on a survey of 1,500 American pastors' media use in March and April 2020, Campbell (2020a) proposes to distinguish between three analytical strategies for religious communities' and actors' media use. First, transferring church online involves simply broadcasting or livestreaming a traditional worship service online, thereby replicating the analogue practice as precisely as possible. Second, translating church online involves adaptation and "some innovation to worship rituals and spaces" (Campbell 2020a, p. 10). Third, transforming church, the least adapted strategy, involves an exploration of the types of gatherings facilitated by digital technology as well as engagement with the need to support and build community voiced by the users (Campbell 2020b). Summing up the 10 lessons learned from the pandemic experience, Campbell and Shepherd (2021) argue that the pandemic should be a catalyst for religious leaders to reconsider their understanding of the relationship between online and offline culture: "Current and future ministry plans should see online and offline strategies as complementary, or two sides of the same coin." (p. 22) As religious communities have embraced technology, they have demonstrated religious resilience and creativity, potentially causing long-lasting cultural and technological changes ensuring that the religious community is not left behind in the future.

In regard to the character of digital religion during the COVID-19-pandemic, Hazel $\mathrm{O}^{\prime}$ Brien finds that the most profound changes concern the increased visibility and accessibility of religion (O'Brien 2020). Thus, the question of delocalization and upscaling has become prevalent: with the digitization of religion, "media help transform local debates into national ones" (Langer et al. 2011, p. 107). In this article, we show how the increased visibility and accessibility of digital religion generates a potential for religious conflicts, but that this is manifested in very different ways among religious majority and minority communities in Denmark.

\section{Results}

In April 2020, Harvard economist Dani Rodrik posted a striking comment on Twitter: "COVID-19 has turned countries into exaggerated versions of themselves" (@rodrikdani, 6 April 2020). This comment invites us to speculate about the ramifications of the extraordinary situation of COVID-19 lockdowns for religions in Denmark and evaluate them in terms of the light they may shed on dynamics, logics, and power relations of pre- and post-COVID conditions. We will present material showing the main considerations and conflicts related to the digitization as they emerge in the majority Lutheran church and in minority Muslim organizations. The comparison we conducted is not systematic as the COVID-19 lockdown affected majority and minority religions in Denmark quite differently. The difference in impact is interestingly not to any significant extent due to differences in legal treatment. While the official treatment of majority and minority religions as illustrated by the video message by minister Joy Mogensen started out in different ways, the legal treatment of majority and minority religions soon converged. The restrictions on majority and minority religions during the gradual reopening of society in the fall of 2020 and during the second lockdown in the winter of 2020 and spring of 2021 were thus identical. Differences in how the COVID-19 lockdown and the subsequent digitization of religion 
affected religious life are therefore an expression of the underlying structures of majority and minority religions in Denmark and their relevance for the digitization of religion.

\subsection{Majority Case: Digital Communion in Folkekirken?}

Within a few days after the Danish Prime Minister's announcement of the forthcoming lockdown of Danish society, pastors from the national church started to produce online material that was posted on either the official website, YouTube channel, or Facebook site of the congregations. While most attention was given to the cancellation of various events, many pastors also offered themselves as conversational partners (via telephone or email) for those in need of pastoral care, and they recommended parishioners to help sick and weak neighbors with practical doings such as grocery shopping and dog walking (FUV 2020, p. 144).

A few pastors, however, quickly started to attend to the ritual needs of the parishioners, and on the first Sunday after the Danish Prime Minister's speech, texts and videos of sermons were posted digitally. Among the YouTube material was a short video, only 3:59 minutes long, of Marianne Gaarden performing the Holy Communion in front of the altar in Maribo Cathedral, posted by the account of Lolland-Falsters (2020) diocese on 15 March 2020 (https:/ / www.youtube.com/watch?v=Oo5yWqiPMEk accessed on 2 July 2021). A short text accompanied the video: “Bishop Marianne Gaarden distributing the communion in Maribo Cathedral. Join in at home by finding a piece of bread and some wine or lemonade that can be eaten and drunk while watching the video." Unlike former communions broadcasted on national television, this particular video encouraged the viewer at home to participate in the ritual. Interestingly, the online material produced in folkekirken during the lockdown in spring 2020 tends to focus almost exclusively on the weekend services and sermons, bringing to the fore a highly event-based, institutional, place-based, and instrumental understanding of religion (cf. Campbell 2020a).

By performing the ritual in her chasuble, Gaarden clearly acted not only as a parish pastor but also as the bishop of Lolland-Falster diocese-a title that was presented to the viewer in the first seconds of the video. As one of ten bishops in the Danish national church, Gaarden and her performance of a virtual communion soon spurred a theological debate that has now lasted for a year (until spring 2021) involving several theologians and representatives from the Danish national church.

The debate took place primarily on the online platform of the Christian newspaper Kristeligt Dagblad, thereby offering a platform for theological discussion accessible to readers nationwide. Discussions of digital communion and religious practice have simultaneously flourished in other Christian communities worldwide, e.g., in England (Parish 2020), Germany (Hörsch 2020), The United States of America (Campbell 2020b), Poland (Morón et al. 2021; Przywara et al. 2021; Sulkowski and Ignatowski 2020), Romania (Tudor et al. 2021), and Spain (Sabaté Gauxachs et al. 2021) as well as in Roman Catholicism more generally (Foley 2021). Just as in other countries, the Danish debate concerns liturgical doctrines such as bodily co-presence of the congregation, the embodiment of Christ as real presence, ritual efficacy and plasticity, sacramental emergencies, and the protestant idea of "priesthood of all believers" (see e.g., Yskes 2020; Garde 2020; Christoffersen 2020; Fenger-Grøndahl 2021; Kristensen and Rasmussen; Holm 2021; Baun 2021; Jacobsen 2021). The theological arguments for and against virtual communion are highly interesting; nevertheless, this section focuses on the changes in the national church caused by the transition from an analogue to a virtual reality. It uses the case of the virtual communion as a prism to study how the digitization of religion has affected the majority religion of Denmark, represented by folkekirken, the Danish national church.

As the case of Marianne Gaarden's virtual communion demonstrates, local handlings of the lockdown suddenly became a public affair and raised a public debate about the possibilities and limitations of online religion. Due to the lack of an official Protestant leader in both Denmark and the world, leaving the national church without a primary religious authority to guide the religious communities' response to media technology (cf. Campbell 
2010, p. 38), the autonomy of the parish has been extensive in terms of media use in folkekirken. In their chapter on "Ritual as a source of conflict", Langer et al. (2011) suggest that "[r]itual connects people, but it is also a source of conflict within and between groups, especially those whose practices are made public by way of media" (p. 93). Similarly, the increased visibility and accessibility of religion during the COVID-19 lockdown of societies due to the digitization of liturgical practices (cf. O'Brien 2020) made local matters public in Denmark. With YouTube, Marianne Gaarden's performance of the communion became accessible to the entire public, and suddenly colleagues and academics became attentive to her media use, generating a national debate. With the digitization of religion, "media help transform local debates into national ones" (Langer et al. 2011, p. 107), and Gaarden's virtual communion was no longer a local sacramental performance but a de-localized, upscaled event accessible to not only all Danish media users, but to media users all over the world.

Thus, the case of Gaarden's virtual communion roused a century-old discussion of (the lack of) leadership in folkekirken. When the Danish constitution was passed under a lot of time pressure in 1849, it encompassed a best endeavor clause obligating the constituting assembly to set the legal framework for folkekirken at a later date. Because this obligation never has been fulfilled, folkekirken does not have an official synod, which makes the regulation of the church an ad hoc task imposed upon the Danish Parliament (Lausten 2008, pp. 81-84). In accordance, Helland (2012) argues that "[i]n most cases, the religious authorities of the church or organization are the "gatekeepers" that control how that organization will utilize Internet technology" (p. 31). But who acted as the (unofficial) leaders of the church — as the "gatekeepers" — during the lockdown of Danish society, laying down the media strategy of the national church? Was it the local pastors weekly serving the parishioners and producing the religious online material? The deans and bishops employing and leading the pastors? The theological experts at the Danish universities? Or was it rather a secular authority, the Minister for Ecclesiastical Affairs, Joy Mogensen, who took on the role as the media strategist of all religious communities in Denmark?

As recent research from other European countries demonstrates, the politically reinforced lockdown of European societies has challenged religious authorities in various religious communities (Bawidamann et al. 2020; Al-Astewani 2021). Restrictions issued in secular spheres pose a serious challenge for the religious authority to uphold its legitimacy, given that religious communities had to comply with the imposed lockdowns in order to show social responsibility and obey the temporary pandemic acts. Different sources of authority were applied by the actors involved in the Danish debate about virtual communion: pastors, including Gaarden, followed their theological beliefs and attended to their parishioners; the academic theologians consulted either the religious texts or traditions; deans and bishops acted in accordance with their hierarchical positions by guiding their subordinates to make use of digital tools, as the Minister for Ecclesiastical Affairs had encouraged them to do, while also respecting the pastors' individual assessment of their parishioners' needs (FUV 2020, p. 72). This means that tradition, text, ideology, and hierarchy became sources of authority in the debate that has not yet been settled due to the lack of leadership in the Danish national church.

Langer et al. (2011) suggest that a ritual has the potential to cause such conflict "precisely because it is ritual, an identity-forming activity and means of reproducing a group's values, social structures, and habitual properties." (p. 121). Following this line of reasoning, the communion-and in this case, the differing theological conceptions of the ritual - had the potential to create a national conflict within folkekirken because of its value as both an identity forming and identity reaffirming ritual. This, combined with the lacking leadership of folkekirken, has made the pastors the main "gatekeepers" deciding how their specific parish should utilize online media. These pastors, of course, had to follow the guidelines imposed by their superiors, that is the deans, bishops, and the Minister for Ecclesiastical Affairs, but ultimately, the media strategy of the national church and thereby 
the practical transition from offline to online religion was implemented by pastors drawing on their individual levels of technological expertise and entrepreneurship.

While Campbell argues that there is a widespread fear among Christian, Muslim, and Jewish communities that new media technologies and the use thereof will undermine established authority structures and gatekeepers (Campbell 2010, p. 186), this case suggests that the authority of religious leaders and the traditional hierarchical structures in folkekirken were altered rather than undermined due to the digitization of religion during the COVID-19 pandemic. Consequently, the parish pastor, at least for a while, became the main actor shaping the strategy, format, and identity of the online church.

\subsection{Minority Cases: Muslim Prayers in Denmark}

In this article, we focus on how religious communities seek to establish continuity between their offline and online practices in order to maintain authority and community cohesion during the COVID-19 lockdown of Danish society. This means that the transition from analogue, offline religion to virtual, online religion and the interplay between the offline and online fora are key themes. The patterns of Muslim reactions to COVID-19 in Denmark show both convergence and differences. The material from the two studies of the reactions of Muslim organizations as well as minority religions in Denmark in general as presented above (Larsen et al. 2021a, 2021b) allows us to draw a picture of minority reactions to the lockdown. The similarities in the reactions were clear. All the mosque associations which had active SoMe accounts shared information about the lockdown, generally cancelling activities or moving them online and very often stressing the need to follow the advice of health authorities. In the fall of 2020, religious minority organizations in Aarhus were asked whether they, during the closure of the houses of worship, had used the buildings for non-public activities like rituals for small groups or for filming rituals or sermons to be shared online. This would be legal, but not something encouraged by the authorities. Among the Christian groups, 29 percent responded in the affirmative, 52 percent said no, and 19 percent did not respond. Among the Muslim groups 15 percent responded in the affirmative, while 85 percent had closed the mosque entirely.

It is difficult to say exactly why almost all mosques were closed entirely, while the non-public use of the buildings was more common among the Christian minorities. Some Muslim leaders mention, among other things, that the Danish police's increased attention to their activities as well as the Prime Minister's utterance that a specific ethnic group was responsible for contamination in Aarhus affected their desire and ability to arrange physical activities (Larsen et al. 2021b). Like Muslims around the world, a major point of concern for Danish Muslims was what to do with the Friday noon congregational prayer (salāt al-jum'a) if the mosque was closed. In many Muslim countries, mosques were closed and people were asked to stay at home, and by mid-March 2020, videos of muezzins replacing the common call to prayer with a call to pray at home was circulated widely (Thurston 2020) and fatwas were issued by muftis in for instance Singapore (Riexinger 2021), Malaysia (Alshehri 2020) and Indonesia (Syatar et al. 2021). The closure of mosques was intended to curb virus transmission, but it obviously also played a larger role in creating the right form of atmosphere:

The closure of the mosques was another important cue or sign as to the seriousness of the virus, identified as important by participants because the mosques are central to community worship that is a key part of Muslim community life and consequently mosques are rarely if ever closed. (Hassan et al. 2021, p. 5).

As the jum'a is basically a revised version of the daily midday prayer, with some of the supplications (raka 'ah) replaced by the Friday sermon (khutba), this meant that the jum'a could be suspended and replaced by a midday prayer. This was the common reaction for Muslim minorities in, for instance, Bosnia (Begovic 2020), Italy (Gori 2021), Poland (Kostecki and Piwko 2021), and Switzerland (Bawidamann et al. 2020). Yet for British Muslims, the situation was more complex as the topic of mosque closure produced what is called a "rich and sophisticated spectrum of responses" (Al-Astewani 2021). al-Astewani 
therefore points to the importance of influences from abroad on British Muslim attitudes and distinguishes between (1) the bonds which derive from the Muslim community being a migrant community sustaining solid relation to previous home countries and (2) the theological bonds arising from the association with a global Muslim community, the ummah. al-Astewani also distinguishes between an "international" influence from the Muslim world and a "regional" influence from Muslim communities in other Western states. In relation to Muslim communities in Denmark, it is obvious that there is a clear connection between the general close-down of mosques around the world, including the countries from which many Danish Muslims can trace their family background (for instance Turkey and Morocco), and the relative ease with which mosques were convinced to close down. This is also evident in that some of the mosques that felt a need to keep the mosque open even with no public attendance have ties to Pakistan, where the closing of mosques has been conflictual (Riexinger 2021). Even if the directness of influence from abroad differs among the mosque associations, the existence of some bonds and inspiration is evident from the content that many of the mosques shared on their SoMe profiles, for instance the streaming of lectures or advice from health authorities in Turkey or Bosnia.

The minority religious organizations in Aarhus were also asked whether they increased their online activities during the pandemic. This was the case for 76 percent of the minority Christian groups, but only 62 percent of the Muslim groups (Larsen et al. 2021b). As in most countries around the world, mosques would be closed for communal prayer, and the question arose whether it would in fact be recommendable to perform a Friday prayer behind a virtually present imam and among a group of virtual congregants via a ceremony streamed online. This position was taken by Umar Al-Qadri, the head of the Islamic Centre in Ireland, in his fatwa issued on 12 March 2020 (Gori 2021, p. 69). As was also the case worldwide, according to Gori, only a minority considered the streaming of the Friday prayer a legitimate substitute for the physical Friday prayer. A comparison of the websites of mosque associations after the partial reopening of religious buildings in Denmark in the fall of 2020 shows that most of them have retained the traditional model of non-attendance, which transforms communal prayer into ordinary midday prayer (salat al-zuhr) for those who cannot attend in person. Some mosques stream the sermon (perhaps under the hashtag \#fredagsbøn), while others stream both the sermon and the actual prayer, which suggests that they may consider praying behind a virtual imam legitimate. Except for a video in which a Muslim explains how Copenhagen imams met to discuss how to react to the recommendations from the health authorities immediately after the lockdown, there is no public information about possible intra- and inter-mosque negotiations comparable to the discussion on digital communion in the national church. This suggests that there may be a major difference in regard to access to media and public space in general for internal discussions among majority and minority religious organizations. This statement does, however, need to be qualified. While the different approaches to ritual change did not seem to lead to any internal conflicts known to the public, one ritual performance did so, namely a call to prayer performed in a residential area in Aarhus as part of a collaborative event arranged by the local mosque and the local congregation under the Evangelical-Lutheran Church in Denmark with the purpose of showing solidarity (Kühle 2021). The video of the call to prayer was distributed on SoMe and may illustrate- though in an adverse way-the comment by sociologist of religion David Herbert that " $[t]$ he new media not only facilitate the communication of religious symbols and discourses, but also may intensify affect in the audience/worshipper" (Herbert 2011, p. 637). The call to prayer became a hot political topic and was, as such, discussed in the media but also in the parliament. In the parliament, two bills to ban public calls to prayer were presented but not adopted, though there was consensus in the parliament that if public calls to prayer (with a volume acceptable according to current legislation) became common, legislation may be needed (Kühle 2021). This shows how mediated rituals in minority religions may produce very negative reactions, because the mere mediation not only makes messages available to the majority audience, but also transforms the minority context into a broader context, moving 
from a small scale to a larger scale, a development which, it has been argued, leads to reinterpretations of the intentions of the participants (cf. Langer et al. 2011, p. 121).

It is no easy task to compare the intersection of religion, media, and government restrictions of the majority Lutheran church with that of for instance the Muslim minority communities in Denmark. Unlike the situation for the majority religion, Muslim organizations in Denmark are not connected in one overall organization. There are approximately 185 mosques in Denmark, but not all of them have an active SoMe profile, and, as stressed above, majority and minority religions are treated differently legally. In some countries, the government treated minority and majority religions differently during the COVID-19 pandemic. This is the case in, for instance, Poland (Kostecki and Piwko 2021, p. 15) and India (Ahmad 2021) but not in Denmark where all religious organizations faced the same regulations. This, however, does not mean that the consequences of the pandemic are the same for majority and minority religions. It is, for instance, obvious that questions of finance were not central to the majority church, although they did matter. Several mosque associations posted online that they were in financial need because they did not receive money from in-mosque fundraising. Not all associations were equally affected, but our interviews in Aarhus showed that almost all minority organizations were affected. For some, like one of the mosques we had selected for a more thorough interview, the Aisha Mosque, this was in fact a serious situation because they did not receive membership dues as it was not possible to be a member of the mosque, and they were therefore entirely dependent on donations.

It is obvious that the reactions among majority and minority religions after the lockdown on March 11 differed. Online reactions by mosque communities in many cases came quite quickly and generally followed what has been called the "responsible minority" approach (Riexinger 2021), i.e., mosque associations followed the recommendations from health authorities. The responsible minority actions were not only performed online; in some cases, COVID-19 test stations were placed on the premises of mosques, or imams became involved in resolving problems related to burial. In fact, a substantial amount of the material transmitted online was recommendations from health authorities. In this way, the online role of mosque associations was also that of cultivating the "good citizen" (Kühle 2021). Other religious minorities also acted as a responsible minority, but the importance attached to civility online was particularly strong among mosque associations. This was clear from how mosque associations often wrote that the authorities have commissioned them to communicate something and also evident from the variety of languages used in the communication that mosque associations may have a role in transmitting and translating information from the Danish authorities. Among the recognized religious communities, which reacted to the spring lockdown, 22 percent communicated only in Danish, while 78 percent communicated in both Danish and another language. In comparison, the online communication by folkekirken is (almost) entirely in Danish. For some of the mosque associations, transnational aspects play a major part. The importance of transnational connections has not been central to Campbell. In When Religion Meets New Media (2010), Campbell mentions how

The internet is presented as a social technology that helps people of shared faith gather together, thereby connecting those from the same religious tradition who would normally be separated by geography, time, or other limitations. This ties in to the image of the Islamic "digital ummah," or the Christian global or networked "body of Christ" (Campbell 2010, p. 39).

But the transnational aspect of digitized religion is far more than just communities connected over distance: It also involves transmitting information in different languages and connecting to specific ethno-religious contexts in ways which are not covered by a generalized reference to a global ummah. 


\section{Discussion}

The 'forced' migration to digital religion is directly related to the question of the consequences of social media for religious change. According to Herbert and Gillespie (2013), these consequences are limited "as long as access and use remain confined to the digitally empowered" (p. 12). The COVID-19 lockdown undoubtedly changed both the production and the consumption of digital religion.

Although this article primarily concerns digital media, we find that the concept of mediation (cf. Meyer 2020) seems to fittingly encapsulate both folkekirken's and Muslim minority communities' media use during the lockdown of Danish society. While the main purpose for both Christian and Muslim communities was to maintain some level of continuity through the digitization of religion, religious change has been an unavoidable consequence of transitioning from offline to online religion. Of course, they had to comply with the inherent media logic of the digital platforms (cf. mediatization), creating opportunities as well as limitations for their digital practices, but, by and large, media technology was used as a tool for want of something better during the lockdown. After the first reopening of Danish society in May 2020, the majority of religious communities decided to return to their analogue, offline activities and thus scale down or completely stop their media usage. For instance, only 33 percent of Muslim communities in the Aarhus region have maintained their online activities after the reopening of Danish society (Larsen et al. 2021b, p. 106), and folkekirken ceased nearly all online activities as public life was reestablished (FUV 2020, pp. 162-63). Just as before the outbreak of COVID-19, "the mediatization of religious communication has yet to make a strong impact" on the religious landscape in Denmark, and "there seems to be either little understanding of the affordances made available by digital media, or no inclination to be swept up by digital media logics" (Knudsen and Nielsen 2019, pp. 115-16). Accordingly, the boundaries between offline and online religion seem to be less blurred than both the pre-pandemic (Campbell and Lövheim 2011; Campbell 2012, 2017; Lundby 2011) and in-pandemic research implies (Campbell and Shepherd 2021). The quick return to an analogue, pre-pandemic religious practice implies that the lockdown accelerated, or even forced, a digitization of religion that was only temporary, which stands in stark contrast to the persistent and ongoing macro structures scrutinized in research on mediatization (Hjarvard 2008; Lövheim 2011).

As both case studies in this article demonstrate, the pandemic state of emergency called for immediate media responses and generated an accelerated or forced digitization entailing a less deliberate and considered media strategy than suggested by Campbell and other scholars researching pre-pandemic digital religion. This means that the religious communities' history and tradition of technology use seem to have been less critical than suggested in Campbell's religious-social shaping of technology approach, which points out history and tradition as one of four core areas decisive for a religious community's conception and application of new technologies (the other three core areas being core beliefs and patterns, negotiation processes, and communal framing and discourses) (Campbell 2010, pp. 59-60).

For instance, all mosque associations with active SoMe accounts used their platform to share information about the lockdown, often stressing the need to follow the advice of health authorities. These actions were not guided by their core beliefs and patterns, as Campbell proposes, but motivated by an attempt to appear as a responsible minority group in Danish society. Furthermore, the case of Gaarden's virtual communion on YouTube that triggered a national debate about digitization of sacramental practices demonstrates the heterogeneity of core beliefs and patterns within folkekirken. The digitization of religious practice was authorized by individual parish pastors, publicly displaying their stance on media use by using (or refraining from using) digital platforms such as Facebook and/or YouTube, meaning that there was no uniform attitude toward the use of digital technology in folkekirken. Instead, a wide array of theological positions appeared both within the church and on Kristeligt Dagblad's media platform. 
Thus, a negotiation process on whether to accept or reject technology started within folkekirken, not because the church was faced with new technology as Campbell suggests (2010, p. 61), but as a result of some religious gatekeepers' actual media use. Because of the heterogeneous response to the digitization of religious practice within folkekirken, so far, more than a year after the first lockdown of Danish society, there has been no communal framing and discourses about media use, and presumably, there will not be any in the near future-or at all! Even if there is a common "public discourse that validates the technology within the community or creates boundaries for acceptable use in light of established community values" (Campbell 2010, p. 62) in folkekirken, it is one that accepts the theological diversity and thereby the broadness of stances to media use without paving the way for a common future media strategy.

Overall, the results of this article's case studies indicate that Campbell assumes a theological homogeneity and uniformity in media usage within each religious community that do not exist. The theological heterogeneity and variation in media usage with religious communities, however, also existed before the outbreak of COVID-19; the pandemic has primarily aroused existing debates and exposed-and presumably reinforced-existing structures of the religious landscape in Denmark.

On this basis, we propose that there is a risk that the importance of theological positions is overemphasized in research on religious communities' media usage and digitization strategies. While theological positions are not unimportant, research indicate that majority/minority status in some cases is more important. This has outside of a media context, for instance, been suggested by a study on perceptions of trust investigated in an experimental research design in Bangladesh and in West Bengal, which found that the level of trust is "not driven by religious identity per se but is highly influenced by minority or majority status" (Gupta et al. 2018). Similarly, reactions to COVID-19 have shown that local circumstances often trump transnational ideological orientations (Riexinger 2021, p. 138).

Furthermore, the resources as well as the societal status and position of a religious community seem to be decisive for how media technology is conceived of and implemented. Pastors from the Danish majority religion were not hesitant to post their religious practices online directly from the closed church buildings despite harsh criticism from colleagues and academics, whereas leaders from religious minority communities refrained from doing so, partly because of the lack of resources to do so and partly because of the intense media coverage of (the few) ethnic and religious minority groups failing to perform social distancing as recommended by Danish health authorities. This overly 'good' behavior of many mosques, implied by their civic dissemination of information about the health authorities' recommendations, predates-and was therefore not conditioned by-specific suggestions that Muslims were not respecting social distancing. The communication was neither aimed at nor successful in contravening these suggestions as the messages were little reported in the media. Thus, religious communities' digitization of religion correlated with majority-minority structures, making it less risky for the religious majority to increase the visibility and accessibility of their religious practices online than for the religious minorities that risked being publicly exposed as irresponsible citizens.

Compared to the extensive attention to the behavior of ethnic and religious minorities from both Danish police, Parliament, and the Prime Minister, Bishop Marianne Gaarden's religious practice online exemplifies how the majority religion enjoys larger acceptance and less negative media coverage than religious minorities. By performing the Holy Communion online, Gaarden promoted a communal religious practice that diverged from the conception of religion of the Minister for Ecclesiastical Affairs, Joy Mogensen. In her address to the religious communities in Denmark on 12 March 2020, Mogensen appeared to convey a quite individualized understanding of religion as being mainly about coping and pastoral care. Neither communal aspects of religion, sacramental practices, nor rituals were mentioned by Mogensen, thereby advocating a protestant conception of religion that emphasized individual belief and diakonia as the core aspects of religion. Gaarden challenged Mogensen's conception of religion by centering her digital practice on the 
communal ritual of the Holy Communion, which indicates that Gaarden advocates a community-based conception of religion. Representatives of minority religions will have less access to challenge the dominant ideas about the position of religion in society, as clearly illustrated by the strong political reactions to one instance of a Muslim call to prayer, which was part of a Christian-Muslim initiative to show solidarity in a time of crisis, but which was presented as an attempt to dominate public space.

Dani Rodrik's Twitter comment about how COVID-19 transformed countries into exaggerated versions of themselves seems to have some truth in the case of majority and minority religions in Denmark. The COVID-19 pandemic did in fact exaggerate the asymmetry between minority and majority religions in different ways: financially, for instance, but also in terms of how the media presented a 'we' and a 'them'. The temporary legal and religious changes introduced by the pandemic may translate into religious and legal changes in the long run. Some religious organizations may continue their online activities; some religious leaders and lay people may think differently about their rituals. Because of the emergence of the postsecular consciousness that religion as a societal institution is not going to go away anytime soon, Mogensen's appeal to religious minorities to cooperate with state authorities seems to represent a new direction in religion-state relations; a direction if not created then at least catalyzed by the extraordinary conditions of the COVID-19 pandemic lockdowns.

Author Contributions: Conceptualization, L.K. and T.L.L.; methodology, L.K. and T.L.L.; validation, L.K. and T.L.L.; investigation, L.K. and T.L.L.; resources, L.K. and T.L.L.; data curation, L.K. and T.L.L.; writing-original draft preparation, L.K. and T.L.L.; writing-review and editing, L.K. and T.L.L.; visualization, T.L.L.; supervision, L.K. and T.L.L.; project administration, L.K. and T.L.L. All authors have read and agreed to the published version of the manuscript.

Funding: This research received no external funding.

Informed Consent Statement: Informed consent was obtained from all subjects involved in the study.

Conflicts of Interest: The authors declare no conflict of interest.

\section{Notes}

1 Dora (2018) has proposed to distinguish between the hyphenated "post-secular", which indicates a break with the secular condition, and the unhyphenated "postsecular," which describes an ongoing secular condition. Drawing on Jürgen Habermas' theory on postsecularity (Habermas 2008, 2012), in this article we use the unhyphenated version, because Habermas does clearly limit his use of the term to what he defines as the secular and secularized societies of Europe and countries such as Canada, Australia, and New Zealand. In these countries, "religion maintains a public influence and relevance, while the secularistic certainty that religion will disappear worldwide in the course of modernization is losing ground" (Habermas 2008, p. 21).

2 The scope of this study is similar to the scope of the mapping project 'Religion in Aarhus' conducted by Centre for Contemporary Religion in 2013. The 'Religion in Aarhus' project is about to be repeated in 2022, making the 2020 COVID-19 survey (Larsen et al. 2021b) a prelimirary study. The specific Aarhus area is outlined in this map: https://samtidsreligion.au.dk/fileadmin/ Samtidsreligion/Religion_i_Aarhus_2013/online_med_forside.pdf\#page=483. Accessed on 2 July 2021.

\section{References}

Ahmad, Nehaluddin. 2021. Protecting the Rights of Minorities under International Law and Implications of COVID-19: An Overview of the Indian Context. Laws 10: 17. [CrossRef]

Al-Astewani, Amin. 2021. To Open or Close? COVID-19, Mosques and the Role of Religious Authority within the British Muslim Community: A Socio-Legal Analysis. Religions 12: 11. [CrossRef]

Alshehri, Khaled Abdulaziz. 2020. The Ruling of Holding Friday Prayer at Home During COVID-19 Pandemic. Journal of Islamic Sciences 3: 23-56.

Baun, Johannes. 2021. Professor: Liturgi er Lige så Kompleks og Smuk som en Symfoni. Kristeligt Dagblad. March 26. Available online: https:/ / www.kristeligt-dagblad.dk/ide-tanke/professor-liturgi-er-lige-saa-kompleks-og-smuk-som-en-symfoni (accessed on 2 July 2021).

Bawidamann, Loïc, Laura Peter, and Rafael Walthert. 2020. Restricted religion. Compliance, vicariousness, and authority during the Corona pandemic in Switzerland. European Societies 23: 637-57. [CrossRef]

Begovic, Nedim. 2020. Restrictions on Religions due to the covid-19 Pandemic: Responses of Religious Communities in Bosnia and Herzegovina. Journal of Law, Religion and State 8: 228-50. [CrossRef] 
Campbell, Heidi A. 2010. When Religion Meets New Media. London: Routledge.

Campbell, Heidi A. 2012. Introduction: The rise of the study of digital religion. In Digital Religion: Understanding Religious Practice in New Media Worlds. Edited by Heidi A. Campbell. London: Routledge, pp. 1-21.

Campbell, Heidi A. 2017. Surveying Theoretical Approaches within Digital Religion Studies. New Media E Society 19: 15-24. [CrossRef]

Campbell, Heidi A. 2020a. Religion Embracing and Resisting Cultural Change in a Time of Social Distancing. In Religion in Quarantine: The Future of Religion in a Post-Pandemic World. Edited by Heidi A. Campbell. Ebook. pp. 9-14. Available online: https: / / oaktrust.library.tamu.edu/handle/1969.1/188004 (accessed on 2 July 2021). [CrossRef]

Campbell, Heidi A. 2020b. What Religious Groups Need to Consider When Trying to Do Church Online. In Digital Ecclesiology: A Global Conversation. Edited by Heidi A. Campbell. Ebook. pp. 49-52. Available online: https:// oaktrust.library.tamu.edu/handle/1969 $.1 / 188698$ (accessed on 2 July 2021). [CrossRef]

Campbell, Heidi A., and Mia Lövheim. 2011. Introduction. Information, Communication \& Society 14: 1083-96. [CrossRef]

Campbell, Heidi A., and Sophia Osteen. 2020. Research Summaries and Lessons on Doing Religion and Church Online. Research and Resources on Religion Online I Research Summaries of Doing Religion Online. Available online: https:/ / oaktrust.library.tamu.edu/ handle/1969.1/187806 (accessed on 19 May 2021).

Campbell, Heidi A., and Troy Shepherd. 2021. What Should Post-Pandemic Religion Look Like? 10 Trends Religious Groups Need to Understand to Survive and Thrive in the Next Decade. Ebook. Available online: https://oaktrust.library.tamu.edu/handle/1969.1/192408 (accessed on 2 July 2021). [CrossRef]

Carlsen, Hjalmar Bang, Jonas Toubøl, and Benedikte Brincker. 2020. On solidarity and volunteering during the COVID-19 crisis in Denmark: The impact of social networks and social media groups on the distribution of support. European Societies 23: $122-40$. [CrossRef]

Carneiro, Larissa. 2015. The implication of technology in mediatisation and mediation approaches to religious studies. Culture and Religion 16: 51-65. [CrossRef]

Christoffersen, Philip. 2020. Præster: Derfor vil vi ikke uddele nadver digitalt. Kristeligt Dagblad. March 25. Available online: https:/ / www.kristeligt-dagblad.dk/kirke-tro/praester-derfor-vil-vi-ikke-uddele-nadver-digitalt (accessed on 2 July 2021).

Danmarks Statistik. 2020. It-Anvendelse i Befolkningen 2020. Available online: https://www.dst.dk/da/Statistik/Publikationer/ VisPub?cid=29450 (accessed on 18 May 2021).

Dora, Veronica Della. 2018. Infrasecular geographies: Making, unmaking and remaking sacred space. Progress in Human Geography 42: 44-71. [CrossRef]

Fenger-Grøndahl, Malene. 2021. Er digital Nadver en Teologisk Holdbar Praksis? Otte Teologer giver Deres Mening til kende. Kristeligt Dagblad. February 6. Available online: https://www.kristeligt-dagblad.dk/ide-tanke/er-digital-nadver-en-teologisk-holdbarpraksis (accessed on 2 July 2021).

Foley, Edward. 2021. Spiritual Communion in a Digital Age: A Roman Catholic Dilemma and Tradition. Religions 12: 245. [CrossRef]

Folkekirkens Uddannelses- og Videnscenter (FUV). 2020. Når Folkekirken Skal Spille efter Reglerne—Men uden for Banen Folkekirkens håndtering af Coronaperioden i foråret 2020. Ebook. Available online: https://www.fkuv.dk/_Resources/Persistent/0/7/3/0/0730 5f2673d70b2b89dd4cfb23eef898654e01e7/N\%C3\%A5r\%20folkekirken\%20skal\%20spille\%20efter\%20reglerne\%20-\%20men\%20 uden\%20for\%20banen.pdf (accessed on 2 July 2021).

Garde, Kristine. 2020. Nadver under Coronakrisen: Jeg Foreslår Hjemmets Altergang. Kristeligt Dagblad. March 30. Available online: https:/ / www.kristeligt-dagblad.dk/debatindlaeg/nadver-under-coronakrisen-jeg-foreslaar-hjemmets-altergang-somde-doebte-selv-udfoerer (accessed on 2 July 2021).

Gori, Alessandro. 2021. Home prayer, unattended funerals and social responsibility: Muslims in Italy and the coronavirus outbreak (March-May 2020): Preliminary remarks: The public religious scene and the COVID-19 outbreak in Italy. Tidsskrift for Islamforskning [Scandinavian Journal of Islamic Studies] 15. [CrossRef]

Gupta, Gautam, Minhaj Mahmud, Pushkar Maitra, Santanu Mitra, and Ananta Neelim. 2018. Religion, minority status, and trust: Evidence from a field experiment. Journal of Economic Behavior E Organization 146: 180-205. [CrossRef]

Habermas, Jürgen. 2008. Notes on post-secular society. New Perspectives Quarterly 25: 17-29. [CrossRef]

Habermas, Jürgen. 2012. A Postsecular World Society? On the Philosophical Significance of Postsecular Consciousness and the Multicultural World Society: An interview with Jürgen Habermas by Eduardo Mendieta. SSRC. Available online: http://blogs. ssrc.org/tif/2010/02/03/apostsecular-world-society (accessed on 2 July 2021).

Hassan, Shaima M., Adele Ring, Naheed Tahir, and Mark Gabbay. 2021. How do Muslim community members perceive Covid-19 risk reduction recommendations-A UK qualitative study? BMC Public Health 21: 449. [CrossRef]

Helland, Christopher. 2000. Online-religion/religion-online and virtual communities. In Religion on the Internet: Research Prospects and Promises. Edited by Jeffrey K. Hadden and Douglas E. Cowan. New York: JAI Press, pp. 205-223.

Helland, Christopher. 2012. Rituals. In Digital Religion: Understanding Religious Practice in New Media Worlds. Edited by Heidi A. Campbell. London: Routledge, pp. 25-40.

Herbert, David E. 2011. Theorizing religion and media in contemporary societies: An account of religious 'publicization'. European Journal of Cultural Studies 14: 626-48. [CrossRef]

Herbert, David E., and Marie Gillespie. 2013. Introduction: Social Media and Religious Change. In Social Media and Religious Change. Edited by David Herbert, Marie Gillespie and Anita Greenhill. Berlin: De Gruyter, pp. 1-14. 
Hjarvard, Stig. 2008. The Mediatization of Religion: A Theory of the Media as Agents of Religious Change. Northern Lights: Film E Media Studies Yearbook 6: 9-26. [CrossRef]

Holm, Bo Kristian. 2021. Professor: Digitalt Nadver fejrer man Med sig selv. Er det Ikke Netop det Modsatte af, Hvad nadver er? Kristeligt Dagblad. January 19. Available online: https:/ / www.kristeligt-dagblad.dk/debatindlaeg/professor-digitalt-fejrer-denenkelte-nadver-med-sig-selv-er-det-ikke-netop-det (accessed on 2 July 2021).

Hörsch, Daniel. 2020. Digitale Verkündigungsformate während der Corona-Krise. Eine Ad-hoc-Studie im Auftrag der Evangelischen Kirche in Deutschland. Midi. Ebook. Available online: https://www.mi-di.de/materialien/digitale-verkuendigungsformate-waehrendder-corona-krise (accessed on 2 July 2021).

Jacobsen, Anders-Christian. 2021. Professor i Dogmatik: Digital Nadver er ikke Sværmeri og Truer Ikke det Kristne fællesskab. Kristeligt Dagblad. January 13. Available online: https:/ / www.kristeligt-dagblad.dk/debatindlaeg/professor-i-dogmatik-dendigitale-nadver-er-ikke-svaermeri-og-true-ikke-det-kristne (accessed on 2 July 2021).

Knudsen, Gry Høngsmark, and Marie Vejrup Nielsen. 2019. Exploring the mediatization of organizational communication by religious communities in digital media. MedieKultur 35: 101-21. [CrossRef]

Kostecki, Wojciech, and Aldona Maria Piwko. 2021. Legislative Actions of the Republic of Poland Government and Religious Attitudes of Muslims in Poland during the COVID-19 Pandemic. Religions 12: 335. [CrossRef]

Kristensen, Johanne S. T., and Thomas R. Rasmussen. 2021 Lektor og Sognepræst: Lad os Debattere, om Nadveren kan Formidles Digitalt. Kristeligt Dagblad. January 10. Available online: https://www.kristeligt-dagblad.dk/kronik/lad-os-debattere-omnadveren-kan-formidles-digitalt (accessed on 2 July 2021).

Kühle, Lene, Jørn Borup, and William Hoverd, eds. 2018a. The Critical Analysis of Religious Diversity. Leiden: Brill.

Kühle, Lene, Ulla Schmidt, Brian Arly Jacobsen, and Per Pettersson. 2018b. Religion and State: Complexity in Change. In Religious Complexity in the Public Sphere. Edited by Inger Furseth. Berlin: Springer, pp. 81-135.

Kühle, Lene. 2021. Danish Muslims under COVID-19. Religion and pandemics in a post-secular society. Tidsskrift for Islamforskning [Scandinavian Journal of Islamic Studies] 73. [CrossRef]

La Ferrière, Alexis Artaud de. 2020. Coronavirus: How New Restrictions on Religious Liberty Vary across Europe. The Conversation. Available online: https:/ / theconversation.com/coronavirus-how-new-restrictions-on-religious-liberty-vary-across-europe-13 5879 (accessed on 21 May 2021).

Langer, Robert, Thomas Quartier, Udo Simon, Jan Snoek, and Gerard Wiegers. 2011. Ritual as a Source of Conflict. In Ritual, Media, and Conflict. Edited by Ronald L. Grimes, Ute Husken, Udo Simon and Eric Venbrux. Oxford: Oxford University Press, pp. 93-132.

Larsen, Tina Langholm, Anne Lundahl Mauritsen, Lene Kühle, Jørn Borup, and Marianne Qvortrup Fibiger. 2021a. ‘Vi har lukket ned for alle aktiviteter': Håndteringen af COVID-19-krisen hos anerkendte trossamfund i Danmark. Religion i Danmark 10: 78-91.

Larsen, Tina Langholm, Anne Lundahl Mauritsen, Simone Agner Sothilingam, Lene Kühle, Jørn Borup, and Marianne Qvortrup Fibiger. 2021b. Religiøs forandring i en krisetid: Et case-studium af aarhusianske religionsgruppers håndtering af COVID-19-pandemien i efteråret 2020. Religion i Danmark 10: 92-113.

Lausten, Martin Schwarz. 2008. Kirkens historie i Danmark: Pavekirke, Kongekirke, Folkekirke, 2nd ed. Sabro: Landsforeningen af Menighedsråd.

Lolland-Falsters, Stift. 2020. Nadver. March 15. Available online: https:/ /www.youtube.com/watch?v=Oo5yWqiPMEk (accessed on 14 May 2021).

Lövheim, Mia. 2011. Mediatisation of religion: A critical appraisal. Culture and Religion 12: 153-66. [CrossRef]

Lundby, Knut. 2011. Patterns of belonging in online/offline interfaces of religion. Information, Communication E Society 14: 1219-35. [CrossRef]

Markkola, Pirjo, and Ingela K. Naumann. 2014. Lutheranism and the Nordic welfare states in comparison. Journal of Church and State 56: 1-12. [CrossRef]

Meyer, Birgit. 2020. Religion as Mediation. Entangled Religions 11. [CrossRef]

Mogensen, Joy. 2020. Kirkeminister med kraftig opfordring til trossamfund. Kirkeministeriet. March 12. Available online: https: //www.km.dk/aktuelt/singlevisning/kirkeminister-med-kraftig-opfordring-til-trossamfund/ (accessed on 20 May 2021).

Morón, Marcin, Magdalena Biolik-Morón, and Krzysztof Matuszewski. 2021. Alterations in Religious Rituals Due to COVID-19 Could Be Related to Intragroup Negativity: A Case of Changes in Receiving Holy Communion in the Roman Catholic Community in Poland. Religions 12: 240. [CrossRef]

Nielsen, Marie Vejrup, and Lene Kühle. 2011. Religion and state in Denmark: Exception among exceptions. Nordic Journal of Religion and Society 24: 173-188. [CrossRef]

O'Brien, Hazel. 2020. What does the rise of digital religion during Covid-19 tell us about religion's capacity to adapt? Irish Journal of Sociology 28: 242-46. [CrossRef]

Olesen, Thomas. 2020. Media and Politics: The Danish Media System in Transformation? The Oxford Handbook of Danish Politics. [CrossRef]

Parish, Helen. 2020. The Absence of Presence and the Presence of Absence: Social Distancing, Sacraments, and the Virtual Religious Community during the COVID-19 Pandemic. Religions 11: 276. [CrossRef]

Przywara, Barbara, Andrzej Adamski, Andrzej Kiciński, Marcin Szewczyk, and Anna Jupowicz-Ginalska. 2021. Online Live-Stream Broadcasting of the Holy Mass during the COVID-19 Pandemic in Poland as an Example of the Mediatisation of Religion: Empirical Studies in the Field of Mass Media Studies and Pastoral Theology. Religions 12: 261. [CrossRef] 
Riexinger, Martin. 2021. Islamic Responses to the COVID-19 pandemic in India and Pakistan. Tidsskrift for Islamforskning [Scandinavian Journal of Islamic Studies] 15. Available online: https:/ / tifoislam.dk/article/view/125960 (accessed on 2 July 2021).

Sabaté Gauxachs, Alba, José María Albalad Aiguabella, and Miriam Diez Bosch. 2021. Coronavirus-Driven Digitalization of In-Person Communities. Analysis of the Catholic Church Online Response in Spain during the Pandemic. Religions 12: 311. [CrossRef]

Sivesind, Karl Henrik, and Håkon Solbu Trætteberg. 2017. Does Out-Contracting of Welfare Services Promote Active Citizenship? In Promoting Active Citizenship. Edited by Karl Henrik Sivesind and Jo Saglie. Cham: Palgrave Macmillan. [CrossRef]

Statista. 2021. Active Social Media Penetration in Selected European Countries in 2020. Available online: https://www.statista.com/ statistics /295660/active-social-media-penetration-in-european-countries / (accessed on 2 July 2021).

Sulkowski, Lukasz, and Grzegorz Ignatowski. 2020. Impact of COVID-19 pandemic on organizationof religious Behaviour in different Christian denominations in Poland. Religions 11: 254. [CrossRef]

Syatar, Abdul, Arif Rahman, M. Ilham, Chaerul Mundzir, Muhammad Arif, Hasanuddin Hasim, and Muhammad Majdy Amiruddin. 2021. Qurban Innovation Due to The Covid-19: Experiences from Indonesia. European Journal of Molecular \& Clinical Medicine 7: 1600-14.

Thurston, Alex. 2020. Islamic responses to COVID-19. The COVID-19 Pandemic in the Middle East and North Africa 15: 15-18. [CrossRef]

Tudor, Mihaela Alexandra, Anamaria Filimon Benea, and Stefan Bratosin. 2021. COVID-19 Pandemic Lockdown and Religious Mediatization of Social Sustainability. A Case Study of Romania. International Journal of Environmental Research and Public Health 18: 2287. [CrossRef]

Yskes, Elisabeth. 2020. Kritik: Nadver uden menighed undergraver ritualet. Kristeligt Dagblad. March 23. Available online: https:/ / www.kristeligt-dagblad.dk/kirke-tro/kritik-nadver-uden-menighed-undergraver-ritualet (accessed on 2 July 2021). 